\title{
Gastro-intestinal helminths of ducks: Some Epidemiologic and pathologic aspects
}

\author{
M. A. Yousuf, P. M. Das, Anisuzzaman ${ }^{1}$ and B. Banowary \\ Department of Pathology, Bangladesh Agricultural University, Mymensingh-2202, Bangladesh \\ ${ }^{1}$ Department of Parasitology, Bangladesh Agricultural University, Mymensingh-2202, Bangladesh
}

\begin{abstract}
A total of 206 ducks were subjected to routine postmortem examinations from July 2007 to June 2008 . Of the ducks examined, $167(81.1 \%)$ were infected by one/more species of gastro-intestinal helminths. A total of ten species of helminth parasites were recovered from gastrointestinal tract, of which four species were trematodes namely: Echinostoma revolutum, Notocotylus attenuatus, Hypoderaeum conoideum and Echinoparyphium recurvatum; two were nematodes, namely, Amidostomum anseris, Capillaria contorta; two were cestodes, viz, Hymenolepis coronula and Fimbriaria fasciolaris and two species belonged to acanthocephala such as, Arythmorhynchus anser and Filicollis anatis. Single double and mixed infections were found in 78 (46.7\%), 46 $(27.5 \%)$ and $43(25.8 \%)$ ducks, respectively. Prevalence of gastrointestinal helminth was significantly $(P<0.05)$ higher in female ducks $(82.7 \%)$ than male ducks (77.6\%). Ducks above six month to one year of age were more affected (53.9\%) than the ducks $<6$ month $(15.0 \%)$ and $>1$ year of age (31.1\%). Helminth infection was significantly $(\mathrm{P}<0.05)$ lower in rainy season $(64.9 \%)$ in contrast to summer $(75.7 \%)$ and winter season $(91.1 \%)$. In heavy infections of $E$. revolutum haemorrhagic enteritis were noticed and parasites were firmly attached with the mucosa. E. recurvatum caused thickening of the serosal surface of intestinal wall. $N$. attenuatus produced catarrhal tryplitis characterized by thickening of the villi and formation of oeosinophilic granulomas. Massive infections with $H$. coronula produced inflammatory changes in the small intestine. Grossly petechial haemorrhages to ulcerative lesions were produced by $A$. anseris. In proventriculus circular ulcerative and necrotic areas with degeneration of the glandular tissues were seen. $A$. anser was also found in between the horney and muscular layer of the gizzard where they produced pin pointed haemorrhagic lesions and in severe case parasites were embedded into the mucosal layers of gizzard. For the control of helminths infections mass deworming is necessary.
\end{abstract}

Keywords: Gastro-intestinal helminths, Ducks, Epidemiology, Pathology

\section{Introduction}

The duck population in Bangladesh is 35 million, which comprises about $10 \%$ of the total poultry. Ducks are commonly used for dual purpose (meat and egg) and mostly reared under traditional system (FAO, 1990). Parasitic infection is one of the major constraints in duck rearing in Bangladesh of which helminth infection is common. In fact, ducks are affected by different types of helminths (Anisuzzaman et al., 2005, Farjana et al., 2004, Islam et al., 1988), but very little attention has been paid to study the epidemiologic and pathologic aspects of helminth infections in ducks. Anisuzzaman et al. (2005) observed chronic active liver cirrhosis in ducks due to avian liver flukes infection. Das et al. (2008) observed sign of asphyxia due to tracheal fluke infection. The knowledge about the epidemiology of a disease/infection is essentially necessary to execute a control program successfully. Knowledge about the pathogenesis and pathology of a particular disease is a prerequisite in proper diagnosis of a disease. Considering these points, the present work was planned to study some epidemiology and pathology of gastro-intestinal helminths of ducks in Bangladesh.

\section{Materials and Methods}

A total of 206 indigenous ducks were examined during the period between July 2007 and June 2008 . The ducks brought for diagnosis in a diagnostic centre or purchased from the households and local markets of Mymensingh district were examined. Before slaughtering, the vent area of the ducks was carefully examined to detect any soiling or other signs of diarrhoea. The slaughtered ducks were subjected to routine post-mortem examination following the procedure as described by Fowler (1990). Different parts of the gastro-intestinal tracts were cut and kept in separate petri dishes. Then the different parts of the gastro-intestinal tracts were opened to collect parasites and to detect gross 
pathological lesions produced by them. Collected trematodes, cestodes and acanthocephalan were fixed in alcohol-formol-acetic acid (AFA), stained with Semichon's carmine, dehydrated in graded alcohol, cleared in aneline oil, cleaned in xylene and mounted with Canada balsam. But nematodes were preserved in glycerin alcohol and morphology was studied by preparing temporary slides adding one drop of lacto phenol (Cable, 1957). The parasites were identified according to the keys and description given by Yamaguti (1961) and Soulsby (1982).

The gross pathological lesions were recorded and the affected organs were collected and preserved in $10 \%$ buffered neutral formalin. For histopathological study, suspected tissues were processed, embedded in wax, sectioned at six $\mu$ thickness and stained with haematoxylin and eosin (Luna, 1968). To study the effects of the season on the prevalence of gastro-intestinal helminths, the year was divided into three seasons such as monsoon (July-October), winter (November-February) and summer (March-June) seasons. The ducks were divided into three age categories such as less than 6 months, 6 months to 1 year and more than 1 year of age. In ducklings, sexes were identified by the digital palpation of penis. The data were analyzed statistically by using chi-square test (Mostafa, 1989). Odds ratio and confidence interval were obtained by the formula according to the Schlesselman (1982).

\section{Results and Discussion}

\section{Epidemiological aspects of gastrointestinal helminth infection in ducks}

Exactly 167 (81.1\%) ducks were found infected by one/more species of gastrointestinal helminths, which conformed to the findings of Ahmed (1969) who recorded $66 \%$ prevalence of $H$. lanceolata and E. revolutum infection. But the prevalence rate was much lower than that of Islam et al. (1988); Farjan et al. (2004) and Anisuzzaman et al. (2005) who reported 97\%, 96.7\% and 98.3\% helminth infection. This disparity might be due to variations in the method of study, geo-climatic condition and husbandry practices. Farmers are now more conscious about the deleterious effects of parasites. So, most of them deworm the birds regularly.

A total of ten species of helminth parasites were recovered from gastrointestinal tract of ducks, of which four species were trematodes: Echinostoma revolutum, Hypoderaeum conoideum, Echinoparyphium recurvatum and Notocotylus attenuatus; two were nematodes, namely, Amidostomum anseris, Capillaria contorta; two were cestodes, viz, Hymenolepis coronula and Fimbriaria fasciolaris and two species belonged to acanthocephala, Arythmorhynchus anser and Filicollis anatis. Among 10 species, single, double and mixed (1-5 parasites) infections were found in 78 (46.7\%), 46(27.5\%) and 43(25.8\%) ducks, respectively.

During the study 67 male and 139 female ducks were examined. Among them 52 male (77.61\%) and 115 female (82.7\%) ducks were infected. Higher prevalence of helminth infection in female ducks (Farjana et al., 2004) may be due to their laying and eating habit. Due to lack of balance ration their immune status is questionable. Islam et al. (1988) reported that the prevalence of Tetrameres fissispina was higher in male than female. Betlejewska and Kalisinska (2001) did not find any difference in the prevalence of helminths in two sex groups.

Out of 167 ducks, 25(15.0\%); 90(53.9\%); and 52(31.1\%) ducks found infected in the age < 6 months, 6 months to 1 year and $>1$ year, respectively. Higher prevalence of infection and density of helminths in older ducks were observed by Farjana et al. (2004). Islam et al. (1988) reported that Echistoma robusum was higher in younger ducks (2 to 20 weeks old). Pham et al. (2002) recorded that ducks of 2-4 months ages were mostly infected $(80.7 \%)$ by worms. Prevalence of gastrointestinal helminths in adult ducks may be due to their free ranging system and loose management. Generally ducklings are kept confined to protect them from the predators. As a result they have relatively less chance to be exposed to the source of infections like various terrestrial and aquatic vectors/intermediate hosts of parasites. 
The seasonal variation of helminths infection were observed and recorded in different seasons. The highest rate of infection was observed in winter season (91.1\%) followed by summer $(75.7 \%)$ and rainy season (64.9\%). Seasonal fluctuatiion of helminth infection also observed by the earlier scientist. Anisuzzaman et al. (2005) observed relatively higher infection rate in rainy season (100\%) followed by

summer (98.1\%) and winter (98.0\%). Junkin et al. (2003) reported high prevalence of infection in rainy season but low in fall and winter. The highest rate of infection in winter may be due to pre-patent period and ability of parasites to remain in the host. On the other hand, in winter season ducks are reared in the stagnant water resulting the intermediate hosts like frogs, bettle, earth worms to get chance to infected the hosts.

\section{Pathologic lesions produced by gastro-intestinal helmiths}

E. revolutum produced haemorrhagic enteritis and parasites were firmly attached with the mucosa (Fig. 1). In histopathological examination, cross section of parasites were seen in the lumen of intestine along with some eosinophilic and lymphocytic infiltrations in the lamina propria of large intestine (Fig. 5). This finding conformed the observations of Forester et al. (1994) who observed haemorrhagic enteritis and thickened intestinal mucosa. They also detected extensive destruction and degeneration of the villi caused by the attachment and pressure of the flukes. E. recurvatum produces pathologic lesions as thickening of the intestinal wall, which was noticed from the serosal surface. After longitudinal incision, catarrhal inflammation was observed on the mucosal surface with many anchored parasites. Bhowmik et al. (1987) observed severe enteritis in turkeys due to E. recurvatum. Both the E. revolutum and E. recurvatum have spiny head collar and scaly cuticle (Soulsby, 1982). They remain firmly attached to the site of attachment and give irritation. Hypoderaeum conoideum produced catarrhal to haemorrhagic spots and in heavy infections it produced haemorrhagic enteritis. Parasites were firmly attached with the mucosa of small intestine. $N$. attenuatus produced catarrhal tryplitis characterized by thickening of the villi and formation of oeosinophilic granulomas (Fig. 8). This finding is in the agreements of the observation by Permin and Hensen (1998). Massive infections with $H$. coronula produced inflammatory changes in the small intestine which varied from catarrhal to haemorrhagic enteritis. Microscopically cross-section of scolex of parasite was seen in the mucosa of the intestine (Fig. 7). Permin and Hensen (1998) studied pathogenecity of $H$. lanceolata and found catarrhal enteritis, diarrhoea and death in chickens. Soulsby (1965) observed catarrhal enteritis leading to wasting, emaciation and death in geese. This parasite has rostellum armed with hooks and a large species measuring up to $130 \mathrm{~mm}$ (Soulsby, 1982). Possibly they induced inflammatory response by giving irritations. Grossly petechical haemorrhages to ulcerative lesions were produced by $A$. anseris. In most cases, they remained firmly attached under the horney cornified layer of gizzard (Fig. 2). In proventriculus, circular ulcerative and necrotic areas with considerable tissue reactions and degeneration of the glandular tissues were seen (Fig. 3.). Extensive leukocytic infiltrations and congested blood vessels were the common features. Petechial haemorrhages in the gizzard and ulcerative lesions in the proventriculus in A. anseris are reported by Anisuzzaman et al (2006); Soulsby (1982) and Lapage (1962) in ducks. These parasites deeply penetrate the horny layer of the gizzard and probably during penetration they cause haemorrhages. On the other hand, $A$. anser was found in between the horny and muscular layer of the gizzard. They causing thickening of the horny layer of the gizzard. In some cases, pin pointed raised dark haemorrhagic lesions were seen. The parasites were embedded into the mucosal layers of gizzard (Fig. 6) as observed by longitudinal sections. Anisuzzaman et al. (2005) first reported this acanthocephalan parasite from the gizzards of indigenous ducks in Bangladesh. However, its pathogenecity and pathology were not mentioned in earlier reports. This parasite posses thorny proboscis (Yamaguti, 1961), as they remain in between the horny and muscular layer of the gizzard that produces continuous irritation causing thickening of this layer. 


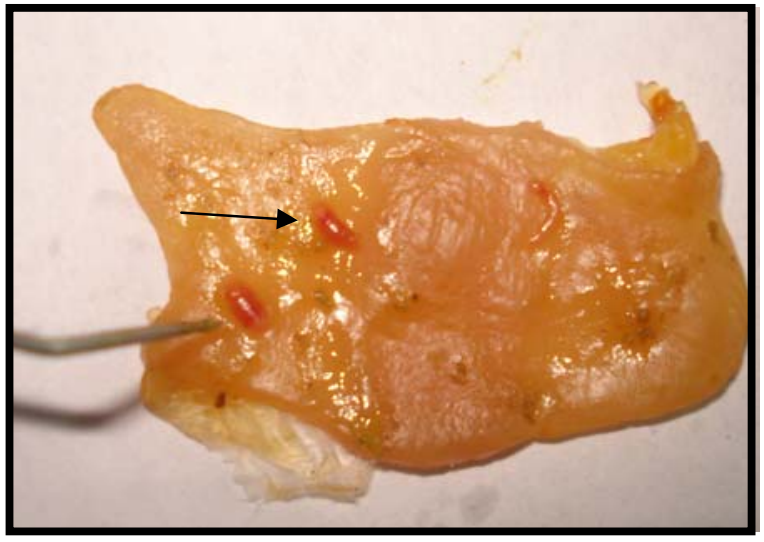

Fig. 1. E. revolutum firmly attached to the mucosa of the large intestine

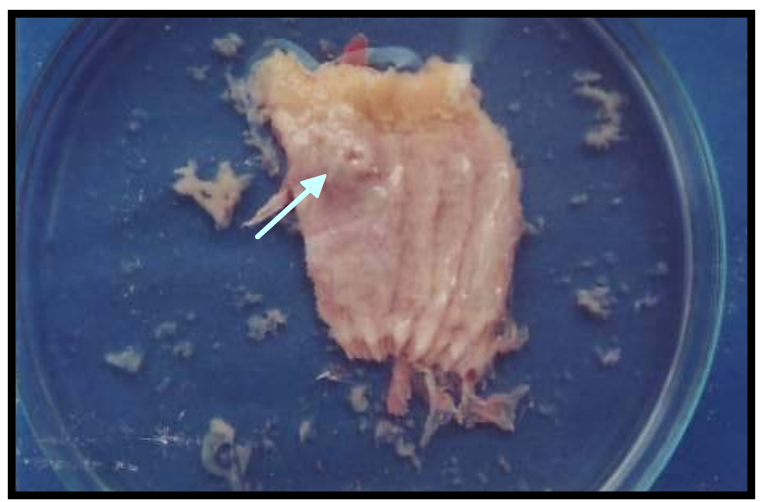

Fig. 3. Circular ulcerative and necrotic areas in the proventriculus in $A$. anseris infection

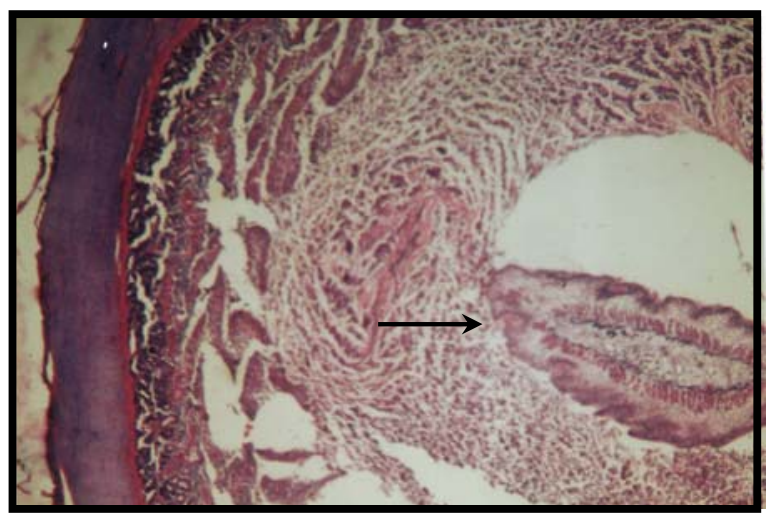

Fig. 5. Cross section of parasite in the lumen of large intestine in $E$. revolutum infection

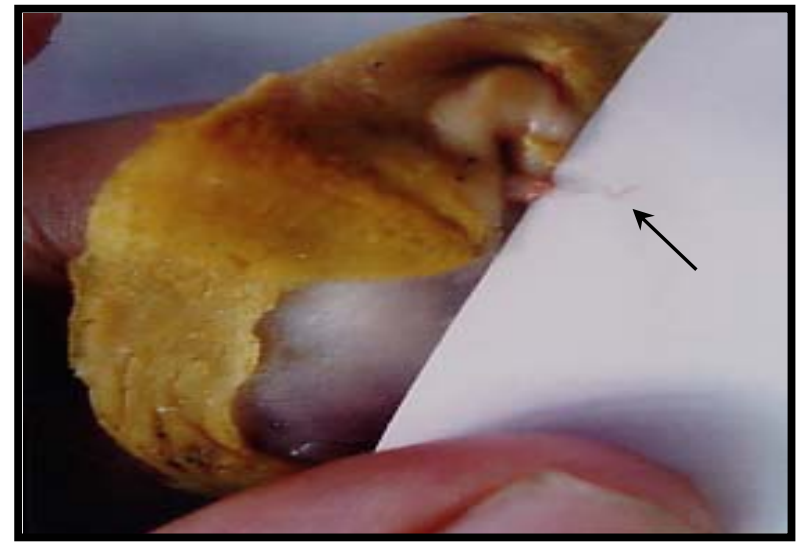

Fig. 2. A. anseris firmly attached under the horney cornified layer of gizzard

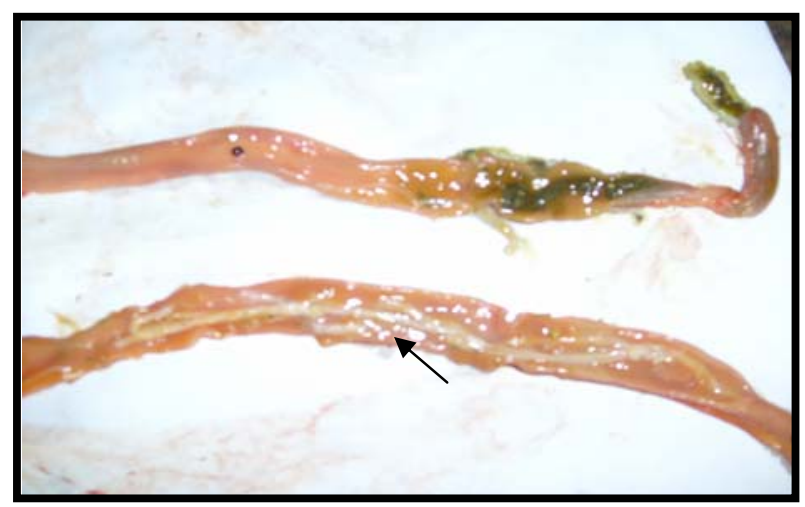

Fig. 4. Catarrhal enteritis in the lumen of intestine and is filled with $H$. coronula

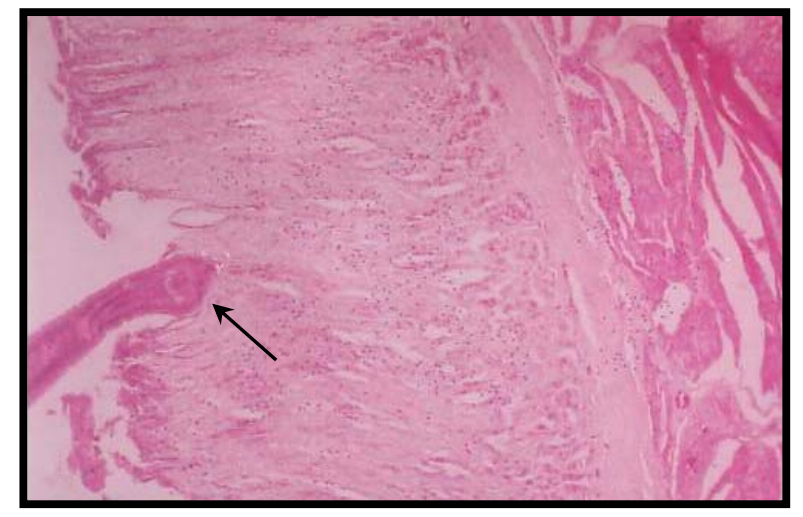

Fig. 6. A. anser is embedded into the mucosal layer of the gizzard 
Table 1. Prevalence (age-wise) of single and mixed infections of gastro-intestinal helminths in ducks

\begin{tabular}{|c|c|c|c|c|c|c|c|}
\hline $\mathrm{S} / \mathrm{N}$ & $\begin{array}{l}\text { Class/ } \\
\text { phylum }\end{array}$ & Prevalence of single and mixed infection & $\begin{array}{l}\text { No of ducks } \\
<6 \text { months } \\
\text { of age (\%) }\end{array}$ & \begin{tabular}{|c|} 
No of ducks 6 \\
months to 1 \\
year of age (\%) \\
\end{tabular} & $\begin{array}{c}\text { No of ducks } \\
>1 \text { of age } \\
(\%)\end{array}$ & Total & $\begin{array}{c}\text { Overall } \\
\text { incidence } \\
(\%)\end{array}$ \\
\hline 1 & \multirow{4}{*}{ Trematoda } & Echinostoma revolutum (Froelich 1802) Loss 1899 & $3(1.8)$ & $8(4.8)$ & $4(2.4)$ & 15 & 8.9 \\
\hline 2 & & Hypoderaeum conoideum (Blocch 1782) Dietz 1909 & $1(0.6)$ & $2(1.2)$ & 0.0 & 3 & 1.8 \\
\hline 3 & & Echinoparyphium recurvatum Listow, 1873 & 0.0 & $3(1.8)$ & 0.0 & 3 & 1.8 \\
\hline 4 & & Notocotylus attenuatus (Rus 1809) Szidat 1933 & 0.0 & $2(1.2)$ & $1(0.6)$ & 3 & 1.8 \\
\hline 5 & \multirow[b]{2}{*}{ Nematoda } & Amidostomum anseris & 0.0 & $4(2.4)$ & $3(1.8)$ & 7 & 4.2 \\
\hline 6 & & Capillaria contorta & 0.0 & $2(1.2)$ & $1((0.6)$ & 3 & 1.8 \\
\hline 7 & \multirow[b]{2}{*}{ Cestoda } & Hymenolepis coronula (Duj, 1845) Railliet 1892 & $6(3.6)$ & $13(7.8)$ & $10(6.0)$ & 29 & 17.4 \\
\hline 8 & & Fimbriaria fasciolaris Pallas 1781 & $3(1.8)$ & $1(0.6)$ & 0.0 & 4 & 2.4 \\
\hline 9 & \multirow{2}{*}{$\begin{array}{l}\text { Acantho- } \\
\text { cephala }\end{array}$} & Arythmorhynchus anser Flurescu 1941 & $2(1.2)$ & $3(1.8)$ & $2(1.2)$ & 7 & 5.2 \\
\hline 10 & & Filicollis anatis (Shrank 1788) Petrotschenko 1956 & 0.00 & $2(1.2)$ & $2(1.2)$ & 4 & 2.4 \\
\hline \multicolumn{3}{|c|}{ Sub total } & 15(9.0) & $40(24.0)$ & 23(13.8) & 78 & 46.7 \\
\hline 11 & \multirow{10}{*}{ 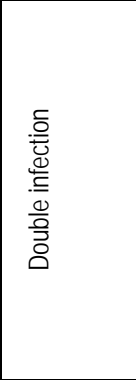 } & Echinostoma revolutum with Hymenolepis coronula & $1(0.6)$ & $3(1.8)$ & $2(1.2)$ & 6 & 3.6 \\
\hline 12 & & Echinostoma revolutum with Fimbriaria fasciolaris & $2(1.2)$ & $1(0.6)$ & 0.0 & 3 & 1.8 \\
\hline 13 & & Echinostoma revolutum with Arythmorhynchus anser & $1(0.6)$ & $1(0.6)$ & $1(0.6)$ & 3 & 1.8 \\
\hline 14 & & Echinoparyphium recurvatum with Hymenolepis coronula & 0.0 & $3(1.8)$ & 0.0 & 3 & 1.8 \\
\hline 15 & & Amidostomum anseri with Hymenolepis coronula & $3(1.8)$ & $2(1.2)$ & $2(1.2)$ & 7 & 4.2 \\
\hline 16 & & Amidostomum anseri with Fimbriaria fasciolaris & 0.0 & 0.0 & $1(0.6)$ & 1 & 0.6 \\
\hline 17 & & Amidostomum anseri with Arythmorhynchus anser & $1(0.6)$ & $2(1.2)$ & $3(1.8)$ & 6 & 3.6 \\
\hline 18 & & Hymenolepis coronula with Fimbriaria fasciolaris & 0.0 & $6(3.6)$ & $3(1.8)$ & 9 & 5.4 \\
\hline 19 & & Hymenolepis coronula with Arythmorhynchus anser & 0.0 & $7(4.2)$ & 0.0 & 7 & 4.2 \\
\hline 20 & & Hymenolepis coronula with Filicollis anatis & 0.0 & 0.0 & $1(0.6)$ & 1 & 0.6 \\
\hline \multicolumn{3}{|r|}{ ( } & $8(4.8)$ & $25(15.0)$ & $13(7.8)$ & 46 & 27.5 \\
\hline 21 & \multirow{15}{*}{ 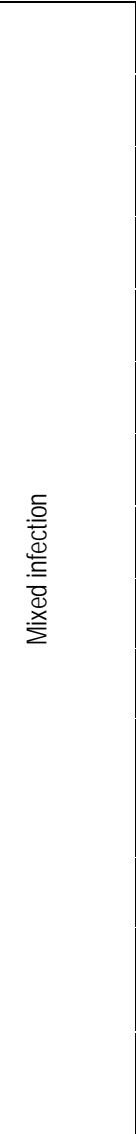 } & $\begin{array}{l}\text { Echinostoma revolutum, Hypoderaeum conoideum and } \\
\text { Amidostomum anseri }\end{array}$ & 0.00 & $2(1.20)$ & $1(0.6)$ & 3 & 1.8 \\
\hline 22 & & $\begin{array}{l}\text { Echinostoma revolutum, Hypoderaeum conoideum and } \\
\text { Capillaria contorta }\end{array}$ & 0.0 & $3(1.8)$ & 0.0 & 2 & 1.2 \\
\hline 23 & & $\begin{array}{l}\text { Echinostoma revolutum, Echinoparyphium recurvatum } \\
\text { and Capillaria contorta }\end{array}$ & 0.0 & $1(0.6)$ & $1(0.6)$ & 4 & 2.4 \\
\hline 24 & & $\begin{array}{l}\text { Echinostoma revolutum, Notocotylus attenuatus and } \\
\text { Amidostomum anseri }\end{array}$ & 0.0 & $1(0.6)$ & $3(1.8)$ & 4 & 2.4 \\
\hline 25 & & $\begin{array}{l}\text { Echinostoma revolutum, Notocotylus attenuatus and } \\
\text { Hymenolepis coronula }\end{array}$ & 0.0 & $1(0.6)$ & $1(0.6)$ & 2 & 1.2 \\
\hline 26 & & $\begin{array}{l}\text { Echinostoma revolutum, Amidostomum anseri and } \\
\text { Capillaria contorta }\end{array}$ & 0.0 & $5(3.0)$ & $3(1.8)$ & 8 & 4.8 \\
\hline 27 & & $\begin{array}{l}\text { Echinostoma revolutum, Amidostomum anseri and } \\
\text { Hymenolepis coronula }\end{array}$ & 0.0 & $2(1.20)$ & 1 & 3 & 1.8 \\
\hline 28 & & $\begin{array}{l}\text { Echinostoma revolutum, Amidostomum anseri and } \\
\text { Arythmorhynchus anser }\end{array}$ & $1(0.6)$ & $1(0.6)$ & $2(1.2)$ & 4 & 2.4 \\
\hline 29 & & $\begin{array}{l}\text { Amidostomum anseri, Capillaria contorta and } \\
\text { Hymenolepis coronula }\end{array}$ & 0.0 & $2(1.2)$ & 0.00 & 2 & 1.2 \\
\hline 30 & & $\begin{array}{l}\text { Amidostomum anseri, Hymenolepis coronula and } \\
\text { Arythmorhynchus anser }\end{array}$ & 0.0 & $1(0.6)$ & $1(0.6)$ & 2 & 1.2 \\
\hline 31 & & $\begin{array}{l}\text { Capillaria contorta, Hymenolepis coronula and } \\
\text { Arythmorhynchus anser }\end{array}$ & 0.0 & $2(1.2)$ & 0.0 & 2 & 1.2 \\
\hline 32 & & $\begin{array}{l}\text { Echinostoma revolutum, Amidostomum anser, } \\
\text { Fimbriaria fasciolaris and Arythmorhynchus anser }\end{array}$ & $1(0.6)$ & $2(1.2)$ & 0.0 & 3 & 1.8 \\
\hline 33 & & $\begin{array}{l}\text { Notocotylus attenuates, Amidostomum anseri, } \\
\text { Hymenolepis coronula and Arythmorhynchus anser }\end{array}$ & 0.0 & 0.0 & $1(0.6)$ & 1 & 0.6 \\
\hline 34 & & $\begin{array}{l}\text { Echinostoma revolutum, Hypoderaeum conoideum, } \\
\text { Amidostomum anseri, Hymenolepis coronula and } \\
\text { Arythmorhynchus anser }\end{array}$ & 0.0 & $1(0.6)$ & 0.0 & 1 & 0.6 \\
\hline 35 & & $\begin{array}{l}\text { Echinostoma revolutum, Echinoparyphium recurvatum, } \\
\text { Notocotylus attenuatus, Capillaria contorta and } \\
\text { Hymenolepis coronula }\end{array}$ & 0.0 & 0.0 & $2(1.2)$ & 2 & 1.2 \\
\hline \multicolumn{3}{|r|}{ ( } & $2(1.2)$ & $25(15.0)$ & $16(9.6)$ & 43 & 25.8 \\
\hline \multicolumn{3}{|c|}{ Total } & $25(15.0)$ & $90(53.9)$ & $52(31.1)$ & 167 & 10 \\
\hline
\end{tabular}




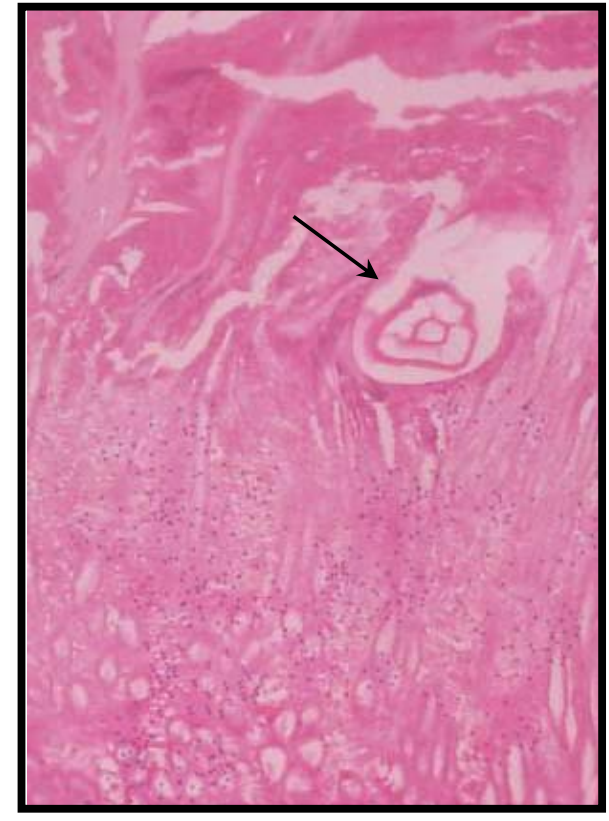

Fig . 7. Cross section of scolex of parasite in the mucosa of the intestine

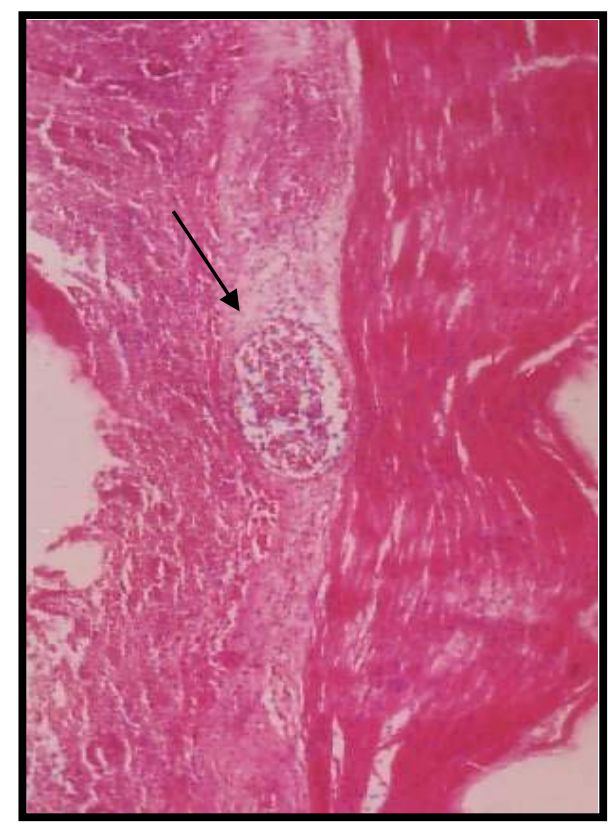

Fig . 8. Eosinophilic gramuloma in the submucosa of caecum due to $N$. attenuatus infection

Table 2. Prevalence of gastro-intestinal helminths in ducks in different ages, sexes, breeds and seasons

\begin{tabular}{|c|c|c|c|c|c|c|}
\hline Determinant & Parameters & $\begin{array}{l}\text { Ducks } \\
\text { examined } \\
(\mathrm{N}=206)\end{array}$ & $\begin{array}{c}\text { Ducks } \\
\text { infected (\%) } \\
(\mathrm{N}=167)\end{array}$ & $\begin{array}{c}\text { Incidence } \\
(\%)\end{array}$ & $\begin{array}{l}\text { Chi- } \\
\text { square } \\
\text { value }\end{array}$ & $\begin{array}{c}\text { Probabilities } \\
\text { associated with } \\
\text { value }\end{array}$ \\
\hline \multirow[t]{2}{*}{ Sex } & Male & 67 & 52 & 77.6 & \multirow{2}{*}{0.7727} & \multirow{2}{*}{$0.3794^{N S}$} \\
\hline & Female & 139 & 115 & 82.7 & & \\
\hline \multirow[t]{3}{*}{ Age } & Up to 6 months & 30 & 25 & 15.0 & \multirow{3}{*}{0.3642} & \multirow{3}{*}{$0.8335^{N S}$} \\
\hline & 6 months up to 1 year & 110 & 90 & 54.0 & & \\
\hline & Above 1 year & 66 & 52 & 31.1 & & \\
\hline \multirow[t]{3}{*}{ Season } & Rainy (July- Oct.) & 57 & 37 & 64.9 & \multirow{3}{*}{17.6969} & \multirow{3}{*}{$0.0001^{\star}$} \\
\hline & Winter (Nov.-Feb.) & 112 & 102 & 91.1 & & \\
\hline & Summer (March-June) & 37 & 28 & 75.7 & & \\
\hline
\end{tabular}

$\mathrm{N}=$ Total ducks examined

\section{Conclusion}

It is suggested that ducks commonly reared in Bangladesh (Indigenous, Khaki Campbell, Jindin) are susceptible to gastrointestinal helminth infection irrespective to age and sex of ducks and seasons of the year. Pathological change due to Hypoderaeum conoideum infections are described, which are not reported before. Mass deworming is essntial routinely at definite interval with safety spectrum of anthelmintic.

\section{Acknowledgements}

This work was funded by Bangladesh Agricultural University Research System (BAURES). So the authors are grateful to BAURES and that are greatly acknowledged. 


\section{References}

Ahmed, S. 1969. Survey on the tyspe of helminths commonly found in the country ducks. Pakistan J. Vet. Sci., 3: 110-112.

Anisuzzaman; Alim, M.A.; Rahman, M.H. and Mondal, M.M.H. 2005. Helminth parasites in indigenous ducks: Seasonal dynamics and effects on production performance, J. of the Bangladesh Agricultural University, 3 (2): 283-290.

Anisuzzaman; Farjana, T.; Alim, M.A.; Khan, M.A.H.N.A.; Mondal, M.M.H. 2006. Amidostomiasis in indigenous Ducks of Bangladesh: Prevalence and pathology. Bangladesh Vet. J. 40 (4): 1-9.

Baki, M.A., Dewan, M.L. and Mondal, M.M.H. 1993. An investigation on the causes of mortality of ducks in Bangladesh. Progress. Agric. 4: 27-33.

Betlejewska, K. M. and Kalisinska, E. 2001. Preliminary survey of echinuriosa of mallard (Anas platyrhynchos) from Northwestern Poland, Falia Universitatis Agriculturae Stetinensis, Zootchnica, 41: 5-10.

Bhowmik, M.K. and Roy, M.M. 1987. Enteric diseases in ducks (Anas platyrhynchos domesticus). Indian Vet. Med. J. 11: 209214.

Cable R.M. 1957. An Illustrated Laboratory Manual of Parasitology, Burgess Publishing Co., 426, South Sixth Street, Minneapolis 15, Minnesota, pp 105-131.

Das, P.M. and Anisuzzaman. 2008. Pathological and Parasitological investigation of an emerging tracheal fluke infection in ducks. Bangladesh Agricultural University research progress. Vol. 18 pp. 5.

FAO, (Food and Agricultural Organization of the United Nations). 1990. The State of World Fisheries and Aquaculture (SOFIA), seventeenth session FAO, Rome.

Farjana, T., Alim, M.A., Das, P.M. and Mondal, M.M.H. 2004 Helminth infection in ducks at free-range and semi intensive farming in two districts of Bangladesh, Bangladesh Vet. J 38:125-134.

Forester, D.J., Kinsella, J.M., Mertins, J.W., Price, R.D. and Turnbull, R.E. 1994. Parasitic helminthes and arthropods of fulvous whistling-ducks in Southern Florida. J. Helminthol. Soci. Washinton, 61(1): 84-88.

Fowler, N.G. 1990. How to carry out a field investgation, In: Poultry diseases, FTW (ed) Bailliere Tindall, London, pp370-400.

Islam, M.R., Shaikh, H. and Baki, M.A. 1988. Prevalence and pathology of helminth parasites in domestic ducks of Bangladesh. Vet. Parasitol., 29: 73-77.

Luna, L.G. 1968. Manual of Histologic Staining Methods of the Armed Forces Institute of Pathology, $3^{\text {rd }}$ edition. McGraw Hill Book Co. New York.

Mostafa, M.G. 1989. Methods of statistics. Fourth edn. Karim Press and Publications, Dhaka, pp. 296-298.

Permin, A. and Hasen, J.W. 1998. Epidemiology, diagnosis and control of poultry parasites, Food and agricultural organization of the United Nations, Rome, pp15-46.

Schlesselman, J.J. 1982. Case Control Studies. Oxford University Press, Oxford. pp. 354.

Soulsby, E.J.L. 1965. Textbook of Veterinary Clinical Parasitology, Vol. I. Helminths. Blackwell Scientific Publications, Oxford.

Soulsby, E.J.L. 1982. Textbook of Veterinary Clinical Parasitology, Vol. I. Helminths. Blackwell Scientific Publications, Oxford.

Yamaguti, S. 1961. Systema Helminthum. Vol. I, Part I, Interscience Publishers, Inc. New York, pp 782-785. 